\title{
Bacteriolytic effect of teicoplanin
}

\author{
Henryk Chmara, ${ }^{*}$ Sandro Ripa, ${ }^{2}$ Fiorenzo Mignini ${ }^{2}$ and EdWard Borowski ${ }^{1}$ \\ ${ }^{1}$ Department of Pharmaceutical Technology and Biochemistry, Technical University of Gdańsk, 80-952 Gdańsk, Poland \\ ${ }^{2}$ Istituto di Microbiologia, Universita degli Studi di Camerino, 62032 (MC) Camerino, Italy
}

(Received 15 October 1990; revised 10 December 1990; accepted 18 December 1990)

\begin{abstract}
The glycopeptide antibiotic teicoplanin belongs to the same group as vancomycin and ristocetin and is a valuable tool for studying the autolytic system of sensitive Gram-positive bacteria. Teicoplanin, at a concentration of $1 \mu \mathrm{g}$ $\mathrm{ml}^{-1}$, caused rapid lysis of exponential phase cells of Streptococcus faecalis. Bacillus spp. were most sensitive to the antibiotic; effective lysis occurred at $0 \cdot 1 \mu \mathrm{g}$ teicoplanin $\mathrm{ml}^{-1}$. The bacteriolytic effect depended on the antibiotic concentration, the growth phase and growth rate of the target organism. Antibiotic added to overnight cultures did not cause lysis. $\mathrm{Mg}^{2+}(50 \mathrm{mM})$ was unable to prevent lysis. Mutants with decreased autolytic activity were more resistant to teicoplanin and lysed more slowly than the wild-type. Growth of bacteria in slightly acidic medium protected the cells against the lytic effect of teicoplanin typically observed at $\mathrm{pH} 7$ or 8 . This pH-dependent antibiotic tolerance was demonstrated with both bacilli and streptococci. Bacterial lysis was prevented by the presence of Ac-L-Lys(Ac)-D-Ala-D-Ala and normal growth was observed when this peptide was added simultaneously with teicoplanin. Bacteria pretreated with teicoplanin, washed and transferred to fresh medium or buffers behaved as if the antibiotic was still present; in neutral or slightly alkaline conditions strong lysis occurred, whereas in acidic buffer only bacteriostasis was observed. In contrast to vancomycin, teicoplanin induced some lysis of bacteria in hypertonic media, presumably by affecting the integrity of the cell membrane.
\end{abstract}

\section{Introduction}

Teicoplanin is an antibiotic chemically related to the group of glycopeptides which also includes vancomycin and ristocetin. It was isolated from the fermentation broth of Actinoplanes teichomyceticus sp. nov. (Parenti et al., 1978; Bardonne et al., 1978) and has outstanding bactericidal activity against Gram-positive pathogenic bacteria (Pallanza et al., 1983; Neu \& Labthavikul, 1983; Fietta et al., 1983). The antibiotic is a mixture of five components of very similar polarity and a sixth, more polar component, all with a similar $M_{\mathrm{r}}$ of about 1900 (Borghi et al., 1984). The name teicoplanin describes the mixture of six components.

The structural unit common to all teicoplanin components consists of a linear heptapeptide aglycone in which two chlorinated $\beta$-hydroxytyrosine units and five substituted phenylglycine residues are interconnected in a tetracyclic structure, carrying D-mannose and $\mathrm{N}$-acetylD-glucosamine moieties. An additional acyl glucosamine residue is present in some components and all contain one of five fatty acid residues. The main feature distinguishing teicoplanin from the other glycopeptide antibiotics is the presence of glucosamine and of aliphatic acid residues (Barna et al., 1984).
The mode of action of teicoplanin was investigated by Somma et al. (1984), who presented data showing that: (a) teicoplanin inhibits peptidoglycan synthesis in intact cells and in 'cell-free' systems; $(b)$ inhibition by teicoplanin is reversed by addition of cell wall material; $(c)$ the antibiotic binds to walls and whole cells, rendering them resistant to the action of lysozyme; and $(d)$ a complex is formed between teicoplanin and the peptide Ac-LLys(Ac)-D-Ala-D-Ala, a synthetic analogue of the terminal peptide moiety of the pentapeptide peptidoglycan precursor. Greenwood et al. (1987) reported that teicoplanin induced lysis of growing Staphylococcus aureus and Streptococcus faecalis and caused morphological changes in these bacteria.

Teicoplanin should be a valuable biochemical tool in the study of peptidoglycan metabolism and its correlation with the autolytic process. The aim of the present study was to investigate some factors that influence teicoplanin-induced lysis in sensitive bacteria such as Bacillus and Streptococcus.

\section{Methods}

Bacterial strains. Bacillus subtilis 168 and the autolysis-defective mutant B. subtilis FJ6 were from the Bacillus Genetic Stock Center 


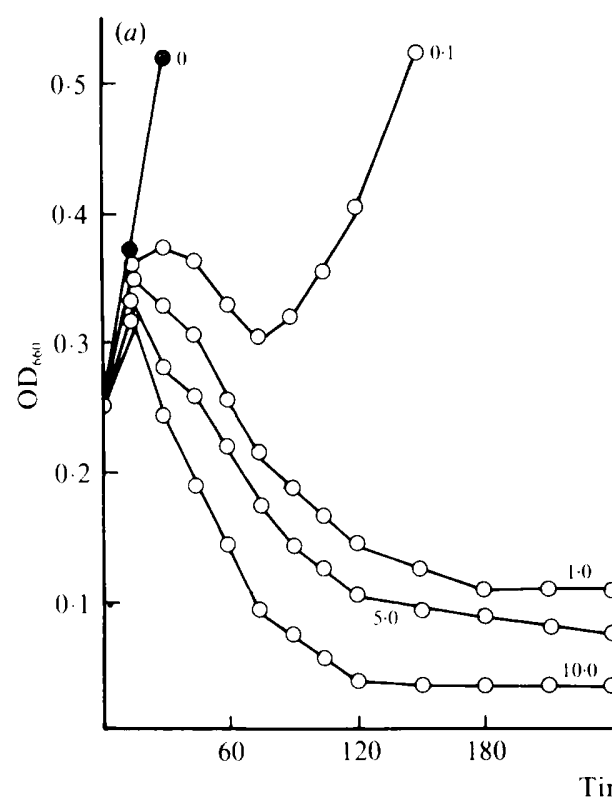

Time $(\min )$

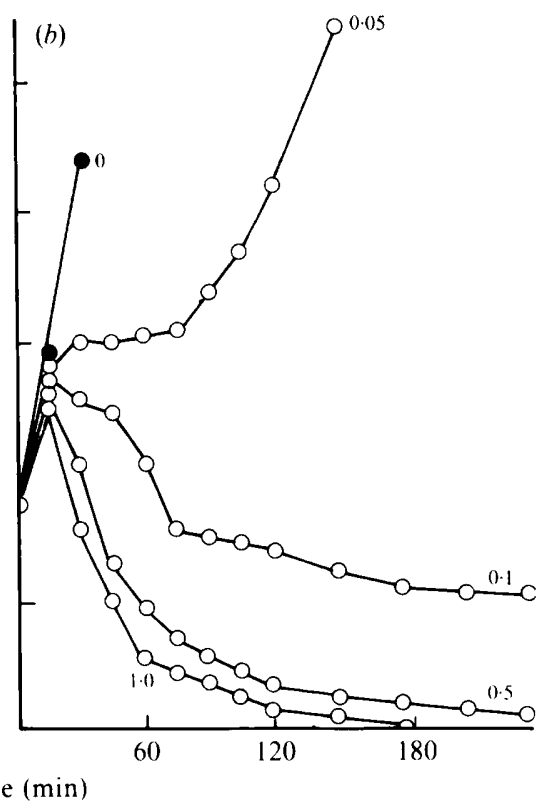

Fig. 1. Bacteriolytic effect of teicoplanin on exponential phase bacterial cells. (a) Strep. faecalis CCM 1875; (b) B. pumilus CCM 1697. To a culture $(10 \mathrm{ml})$ of early exponential phase cells (approx. $2 \times 10^{8} \mathrm{ml}^{-1}$ ) growing in MBD LYC medium, teicoplanin $(100 \mu$ l of an aqueous solution of appropriate concentration) was added at time zero. $\bigcirc$, Untreated cells; $O$, cells treated with teicoplanin at the indicated concentration $\left(\mu \mathrm{g} \mathrm{ml}^{-1}\right)$.
(Columbus, Ohio, USA). B. pumilus CCM 1697 and Strep. faecalis CCM 1875 were obtained from the Czechoslovak Collection of Microorganisms (Bratislava, Czechoslovakia). Micrococcus luteus NCTC 2656 was from the National Institute for Medical Research (Mill Hill, London, UK). Strep. faecalis $8462 \mathrm{Vanco}^{\mathrm{R}}$ was supplied from the micro-organism collection of the Medical Academy of Gdańsk (Poland). Strep. faecium ATCC 9790 and the autolysis-defective mutant LYT-14 were kindly provided by G. D. Shockman (Temple University School of Medicine, Pennsylvania, USA).

Grow'th conditions. Bacteria were grown in Davis minimal broth (Difco) supplemented with $0.4 \%$ glucose, $0.2 \%$ Lab-Lemco (Oxoid), $0.2 \%$ yeast extract (Difco) and $0.2 \%$ Casamino acids (Difco). This medium was called MBD LYC. In 'poor' medium, for slow growth of bacteria, Lab-Lemco, yeast extract and Casamino acids were reduced to $0.02 \%$ and glucose to $0.2 \%$. Hypertonic MBD LYC medium was supplemented with $500 \mathrm{~mm}$-sucrose and $50 \mathrm{~mm}-\mathrm{Mg}^{2+}\left(\mathrm{MgCl}_{2}\right)$. For most experiments the $\mathrm{pH}$ of MBD LYC medium was between 7.0 and 7.1. For experiments of the $\mathrm{pH}$-dependence of lysis, the $\mathrm{pH}$ of the $\mathrm{MBD}$ LYC medium was adjusted with $100 \mathrm{~mm}$-buffers to the following values: $5 \cdot 3$ (Tris/maleate); 6·2, 6.6 and 7.0 (potassium phosphate); and $8.0($ Tris $/ \mathrm{HCl})$

Overnight cultures of bacteria in MBD LYC medium were diluted to approximately $2 \times 10^{7}$ cells $\mathrm{ml}^{-1}$ with fresh medium and incubated at $37^{\circ} \mathrm{C}$ with vigorous agitation. Growth was followed by measuring the optical density of the culture at $660 \mathrm{~nm}$ with a Zeiss spectrophotometer. At the indicated times small volumes $(100 \mu \mathrm{l})$ of an aqueous solution of teicoplanin, or other antibiotics, were added. Chloramphenicol was added as an ethanol solution $(100 \mu l)$ of appropriate concentration.

Pretreatment with teicoplanin. Exponential phase bacteria $(40 \mathrm{ml})$ were treated for $15 \mathrm{~min}$ with teicoplanin $\left(2 \mu \mathrm{g} \mathrm{ml}^{-1}\right)$, centrifuged and washed. The cell suspension was then divided into four aliquots. Cells from each aliquot were harvested, washed and suspended in one of the following media: fresh MBD LYC medium containing $\mathrm{N}$-Ac-LLys(Ac)-D-Ala-D-Ala in 250-fold molar excess relative to teicoplanin fresh medium without peptide; $100 \mathrm{~mm}-\mathrm{Bistris} / \mathrm{HCl}$ at $\mathrm{pH} 6.0$; and $100 \mathrm{~mm}$ Bistris $/ \mathrm{HCl}$ at $\mathrm{pH} 7.5$.

Chemicals. Teicoplanin was a gift from Gruppo Lepetit (Milano, Italy). Vancomycin, methicillin and chloramphenicol were from Sigma. The following peptides, related to the terminal moiety of peptidoglycan precursors, were synthesized in our laboratory: Ac-L-
Lys(Ac)-D-Ala-D-Ala; Ac-L-Lys(Ac)-D-Ala-L-Ala; Ac-L-Lys(Ac)-LAla-D-Ala; Ac-L-Lys(Ac)-D-Ala-D-Leu and Ac-L-Lys(Ac)-D-Ala-Gly.

\section{Results and Discussion}

\section{Teicoplanin-induced lysis in exponential phase bacteria}

It has often been observed that the addition of antibiotics inhibiting cell wall biosynthesis to exponential phase bacterial cultures results in a rapid and extensive lysis (Boman \& Erikson, 1963; Kitano \& Tomasz, 1979; Chmara \& Borowski, 1986; van Heijenoort et al., 1987).

The addition of teicoplanin to cultures of Strep. faecalis CCM 1875 in the early exponential growth phase caused complete lysis. Lysis was not instantaneous and did not begin until at least 15 min after antibiotic addition (Fig. 1a). Effective lysis was observed at antibiotic concentrations ranging from 1 to $10 \mu \mathrm{g} \mathrm{ml}^{-1}$. Teicoplanin at a concentration of $0.1 \mu \mathrm{g} \mathrm{ml} \mathrm{m}^{-1}$ caused lysis for $45 \mathrm{~min}$ followed by regrowth. Teicoplanin at $10 \mu \mathrm{g} \mathrm{ml}^{-1}$ caused total lysis of Strep. faecalis with no regrowth, even after $24 \mathrm{~h}$ of incubation.

The clinical strain of Strep. faecalis, $8462 \mathrm{Vanco}^{\mathrm{R}}$, did not lyse in the presence of teicoplanin even at a concentration of $250 \mu \mathrm{g} \mathrm{ml}^{-1}$. Only minor growth inhibition was observed (data not shown).

B. pumilus CCM 1697 was extremely sensitive to teicoplanin: it lysed rapidly at teicoplanin concentrations of $0 \cdot 1$ to $1 \mu \mathrm{g} \mathrm{ml}^{-1}$ (Fig. $1 b$ ). A concentration of $0.05 \mu \mathrm{g} \mathrm{m}^{-1}$ caused only partial inhibition of growth followed by regrowth after $75 \mathrm{~min}$. After $24 \mathrm{~h}$ incubation in the presence of $0 \cdot 1 \mu \mathrm{g}$ teicoplanin $\mathrm{ml}^{-1}, B$. pumilus 
showed some regrowth, but not exceeding $25 \%$ of the growth of a control culture without the antibiotic. Teicoplanin at $2 \mu \mathrm{g} \mathrm{ml}^{-1}$ caused total lysis of $B$. pumilus with no regrowth, even after $48 \mathrm{~h}$ of incubation.

\section{Effect of growth phase and growth rate on lysis}

Teicoplanin-induced lysis was dependent on the growth phase of $B$. pumilus at the time of addition of the antibiotic. Up to $15 \mathrm{~min}$ after the transfer of overnight culture to fresh medium, addition of $2 \mu \mathrm{g}$ teicoplanin $\mathrm{ml}^{-1}$ caused only growth inhibition (data not shown). This phenomenon, i.e. lack of lysis of non-growing cells, seems to be a feature common to all bacteria and was described by Tuomanen et al. (1986) as phenotypic tolerance.

During the early and late exponential growth phase, teicoplanin, as expected, induced rapid lysis. However, addition of the antibiotic towards the end of exponential growth resulted in an increased delay $(45 \mathrm{~min})$ before lysis started. When the growth rate was clearly declining, addition of the antibiotic caused only partial inhibition of growth instead of lysis (data not shown).

In their experiments on the lysis of Escherichia coli by ampicillin, Boman \& Erikson (1963) showed that the time of lysis was strongly dependent on the growth rate. As shown in Fig. 2, teicoplanin induced lysis after a longer lag phase with slowly growing Strep. faecalis CCM 1875 and lysis was not very extensive.

Our results confirm the finding of Tuomanen et al. (1986) that the rate of bacterial lysis following exposure to cell-wall-inhibitory antibiotics appears to be a direct function of bacterial growth prior to the addition of the antibiotic.

\section{Effect of teicoplanin on growth in hypertonic medium.}

It is of interest that in hypertonic media, teicoplanin at concentrations of $1 \mu \mathrm{g} \mathrm{ml}^{-1}$ and $10 \mu \mathrm{g} \mathrm{ml}^{-1}$, respectively, induced lysis of B. pumilus CCM 1697 and Strep. faecalis CCM 1875 (Fig. 3). In contrast only a bacteriostatic effect was observed with vancomycin and methicillin. This observation suggests that vancomycin and teicoplanin, although closely related, differ in their mode of action. The mechanism of teicoplanin-induced lysis in hypertonic media is unknown. It is possible that teicoplanin, as well as inhibiting peptidoglycan synthesis, exerts some effect on the cytoplasmic membrane.

Reynolds (1971), studying the effect of vancomycin at concentrations of 10 and $50 \mu \mathrm{g} \mathrm{ml}^{-1}$ on growth of reconditioned $B$. megaterium $\mathrm{KM}$ protoplasts, and Rosenthal et al. (1975), carrying out similar experiments with Strep. faecalis ATCC 9790 protoplasts, did not observe any lytic effects.

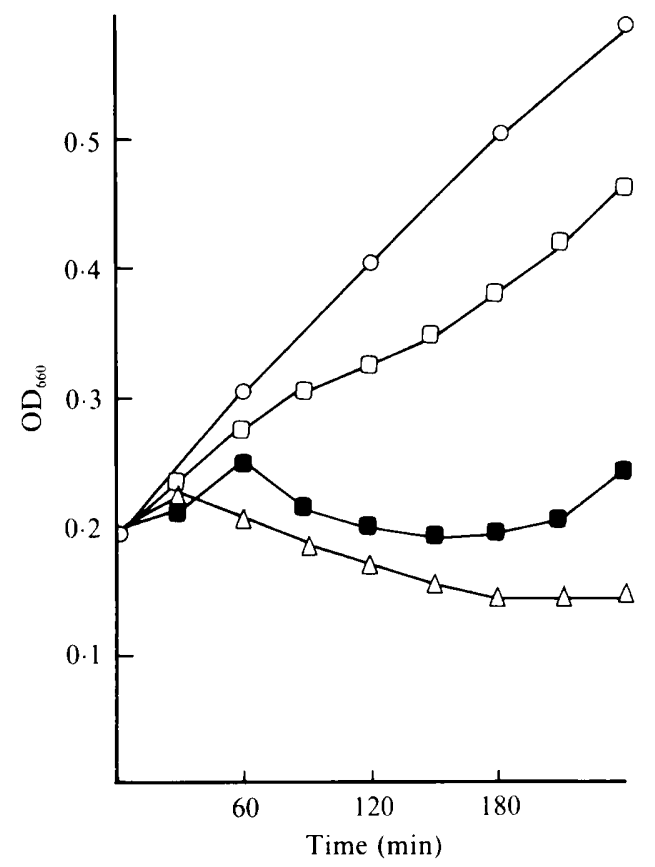

Fig. 2. Action of teicoplanin on slowly growing bacteria. To a culture $(10 \mathrm{ml})$ of early exponential phase cells (approx. $2 \times 10^{8} \mathrm{ml}^{-1}$ ) of Strep. faecalis CCM 1875 growing in MBD LYC 'poor' medium, teicoplanin ( $100 \mu \mathrm{l}$ of an aqueous solution of appropriate concentration) was added at time zero. $\mathrm{O}$, Untreated cells $; \square, 0 \cdot 1 \mu \mathrm{g}$ teicoplanin $\mathrm{ml}^{-1} ; \boldsymbol{\square}, 1 \cdot 0 \mu \mathrm{g}$ teicoplanin $\mathrm{ml}^{-1} ; \triangle, 10 \cdot 0 \mu \mathrm{g}$ teicoplanin $\mathrm{ml}^{-1}$.

Influence of $\mathrm{Mg}^{2+}$ on lysis induced by teicoplanin

Best \& Durham (1964) reported that inhibition of peptidoglycan synthesis and growth in B. subtilis W23 by a low concentration of vancomycin was depressed by $\mathrm{Mg}^{2+}(1.66 \mathrm{mM})$.

We demonstrated that $\mathrm{Mg}^{2+}$, even at a concentration of $50 \mathrm{~mm}$, did not inhibit teicoplanin-induced lysis of $B$. pumilus CCM 1697 and Strep. faecalis CCM 1875 when the antibiotic was used at concentrations of $2 \mu \mathrm{g} \mathrm{ml}^{-1}$ and $10 \mu \mathrm{g} \mathrm{ml}^{-1}$, respectively. The only detectable effect was a prolongation by about $15 \mathrm{~min}$, of the lag phase before lysis. The slope of the lysis curve was identical with that obtained in experiments with teicoplanin in the absence of $\mathrm{Mg}^{2+}$ (data not shown).

\section{Effect of teicoplanin on growth of an autolysis-defective mutant}

Bacteriolysis is not a direct effect of the primary action of cell-wall antibiotics which inhibit the biosynthesis of peptidoglycan at various stages. It has been shown that a secondary effect is a deregulation of bacterial autolysins, enzymes which hydrolyse the existing peptidoglycan, thereby leading to bacterial lysis (Rogers \& Forsberg, 


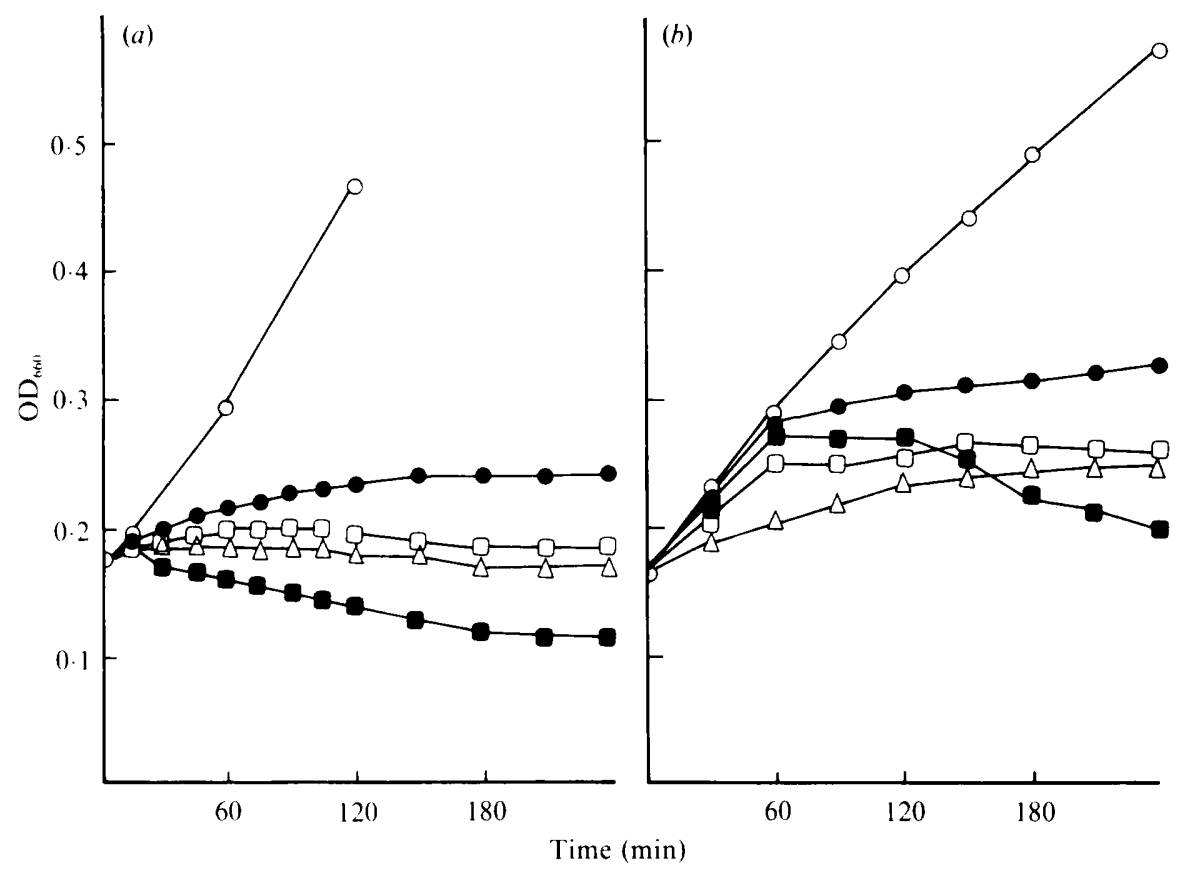

Fig. 3. Effect of teicoplanin on the growth of (a) B. pumilus CCM 1697 and (b) Strep. faecalis CCM 1875 in hypertonic medium. To a culture $(10 \mathrm{ml})$ of early exponential phase cells $\left(2 \times 10^{8} \mathrm{ml}^{-1}\right)$ growing in MBD LYC medium, supplemented with $500 \mathrm{~mm}$-sucrose and $50 \mathrm{mM}-\mathrm{Mg}^{2+}$, teicoplanin, vancomycin or methicillin was added at time zero. (a) $\bigcirc$, Untreated cells; $0,0 \cdot 2 \mu \mathrm{g}$ teicoplanin $\mathrm{ml}^{-1}$; 口, $1 \mu \mathrm{g}$ teicoplanin $\mathrm{ml}^{-1} ; \square, 2 \mu \mathrm{g}$ vancomycin $\mathrm{ml}^{-1}: \triangle, 2 \mu \mathrm{g}$ methicillin $\mathrm{ml}^{-1}$. (b) $\bigcirc$, Untreated cells;, $1 \mu \mathrm{g}$ teicoplanin $\mathrm{ml}^{-1}: \mathbf{\square}$, $10 \mu \mathrm{g}$ teicoplanin $\mathrm{ml}^{-1} ; \square, 10 \mu \mathrm{g}$ vancomycin $\mathrm{ml}^{-1} ; \triangle, 10 \mu \mathrm{g}$ methicillin $\mathrm{ml}^{-1}$.
1971; Best et al., 1974; Tomasz \& Höltje, 1977). Subsequently it was shown (Rogers \& Forsberg, 1971; Ayusawa et al., 1975; Fein \& Rogers, 1976; Rogers et al., 1983) that strains of various micro-organisms deprived of autolysins are lysed less rapidly by antibiotics that inhibit cell wall synthesis than are the parent organisms. The term 'tolerant' was used to describe such strains.

In our studies we used $B$. subtilis 168 and the autolysis defective mutant FJ6. Compared to the corresponding wild-type strain, the autolysis defective mutant FJ6 exhibited much slower rates of lysis in the presence of 1 or $10 \mu \mathrm{g}$ teicoplanin $\mathrm{ml}^{-1}$ (data not shown). The lysis was not fully inhibited because the mutant is not completely deprived of autolysins but retains some activity (Rogers et al., 1983). The main lytic enzyme of B. subtilis 168 is an $N$-acetylmuramoyl-L-alanine amidase (Herbold \& Glaser, 1975). Similar results were obtained when the teicoplanin-induced lysis of Strep. faecium ATCC 9790 and its autolysis-defective mutant LYT 14 were compared. The mutant showed much slower rates of lysis in the presence of teicoplanin $\left(1\right.$ and $\left.10 \mu \mathrm{g} \mathrm{ml}^{-1}\right)$.

\section{Effect of chloramphenicol on lysis}

Further evidence supporting the essential role of autolysins in teicoplanin-induced bacteriolysis was obtained by studying the effect of protein synthesis inhibition by chloramphenicol.

As can be seen from Fig. 4, the addition of $1 \mu \mathrm{g}$ teicoplanin $\mathrm{ml}^{-1}$ caused rapid lysis of B. pumilus CCM 1697 cells. Chloramphenicol at a concentration of $100 \mu \mathrm{g}$

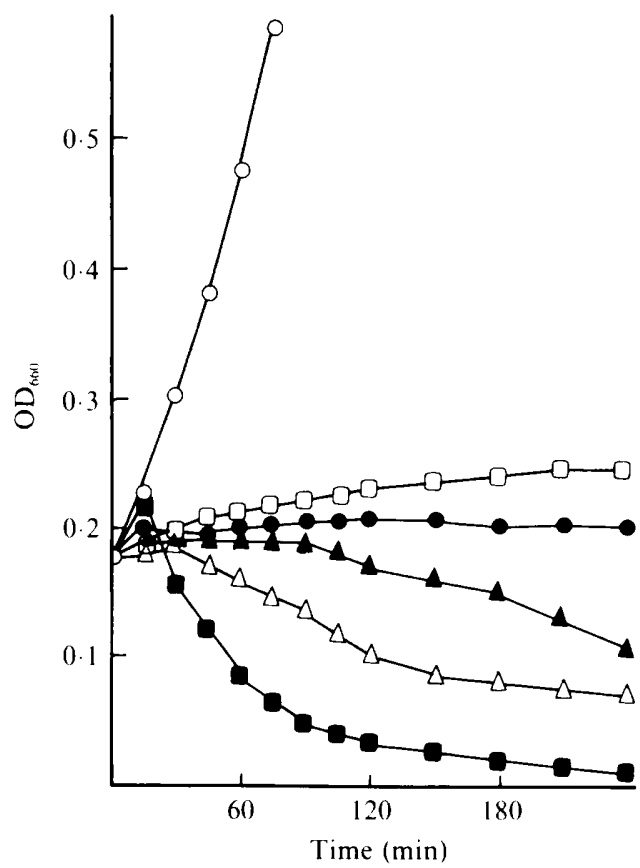

Fig. 4. Effect of chloramphenicol on teicoplanin-induced lysis of $B$. pumilus CCM 1697. To a culture ( $10 \mathrm{ml}$ ) of early exponential phase cells growing in MBD LYC medium, teicoplanin $\left(1 \mu \mathrm{g} \mathrm{ml} \mathrm{ml}^{-1}\right)$ and chloramphenicol $\left(100 \mu \mathrm{g} \mathrm{ml}^{-1}\right)$ were added at different time points. $O$, Untreated cells; $\square$, teicoplanin added at $0 \mathrm{~min} ; \square$, chloramphenicol added at $0 \mathrm{~min}$ : $\triangle$, chloramphenicol added with teicoplanin at $0 \mathrm{~min}$; $\boldsymbol{A}$. , chloramphenicol added at $0 \mathrm{~min}$ with teicoplanin at $15 \mathrm{~min}(\mathbf{\Delta})$ and $30 \mathrm{~min}(\mathrm{O})$

$\mathrm{ml}^{-1}$ inhibited growth, although not completely. When chloramphenicol was added together with teicoplanin the bacteria lysed, but not so extensively as with 
teicoplanin alone. A complete inhibition of lysis was observed when chloramphenicol was added $30 \mathrm{~min}$ prior to the addition of teicoplanin. The effect of lysis inhibition lasted for at least $4 \mathrm{~h}$. Quite similar effects were described by Rogers \& Forsberg (1971), who recorded complete inhibition of lysis of $B$. licheniformis by vancomycin $\left(10 \mu \mathrm{g} \mathrm{ml}^{-1}\right)$ when chloramphenicol $\left(50 \mu \mathrm{g} \mathrm{ml}^{-1}\right)$ was added at least $60 \mathrm{~min}$ before the addition of vancomycin.

The mechanism of chloramphenicol protection is not yet understood. As reported by Tomasz \& Waks (1975) several experiments strongly suggest that this phenomenon is not caused by a deficiency in the number of hydrolase molecules at the cell surface, but rather by a disturbance of the metabolic regulation of the activity of the autolysins.

\section{Induction of lysis of bacterial cells growing in media at different $\mathrm{pH}$}

The response of B. pumilus CCM 1697 and Strep. faecalis CCM 1875 to teicoplanin was dependent upon the $\mathrm{pH}$ of the growth medium. At $\mathrm{pH} 7.0$ or 8.0 the bacteria lysed rapidly after a short lag phase, but only slow lysis could be observed for $B$. pumilus at $\mathrm{pH} 6.2$ and no lysis was detected at $\mathrm{pH} 5.3$. In the case of Strep. faecalis, rapid lysis was observed at $\mathrm{pH} 7.0$ or 8.0 but no lysis was detected at $\mathrm{pH} 6 \cdot 2$. Additional bacterial strains tested (Staphylococcus aureus, Micrococcus luteus, Corynebacterium sp.) exhibited a similar response to the $\mathrm{pH}$ of the medium. These results (data not shown) indicate that appropriate modulation of the $\mathrm{pH}$ of the growth medium produces the typical features of antibiotic tolerance. The cellular response changes from lysis to bacteriostasis. It should be noted that the inhibition of lysis was not associated with slower cell growth in media of low $\mathrm{pH}$. All bacterial strains examined grew equally well at both pH 6.2 and 7.0. Slower growth was observed only in the medium of $\mathrm{pH} 5 \cdot 3$; however, the growth was only about $30 \%$ slower as compared to growth at $\mathrm{pH} 7 \cdot 0$. The tolerance of cells for teicoplanin in media of low $\mathrm{pH}$ was fully reversible. After $90 \mathrm{~min}$ exposure to $1.0 \mu \mathrm{g}$ teicoplanin $\mathrm{ml}^{-1}$ B. pumilus cells growing at $\mathrm{pH} 5 \cdot 3$ started to lyse rapidly after a lag phase of $30 \mathrm{~min}$ when washed and resuspended in medium of $\mathrm{pH} 7 \cdot 0$. This was also found with Strep. faecalis pretreated with $10 \mu \mathrm{g}$ teicoplanin $\mathrm{ml}^{-1}$ at $\mathrm{pH} 6 \cdot 2$.

This phenomenon of bacterial tolerance for teicoplanin at low $\mathrm{pH}$ corroborates the results of Goodell et al. (1976) and Lopez et al. (1976), who found that cell-wall antibiotics, irrespective of their site(s) of action in the biosynthetic pathway of peptidoglycan, exhibit suppressed lytic activity on bacteria growing in media of low $\mathrm{pH}$.

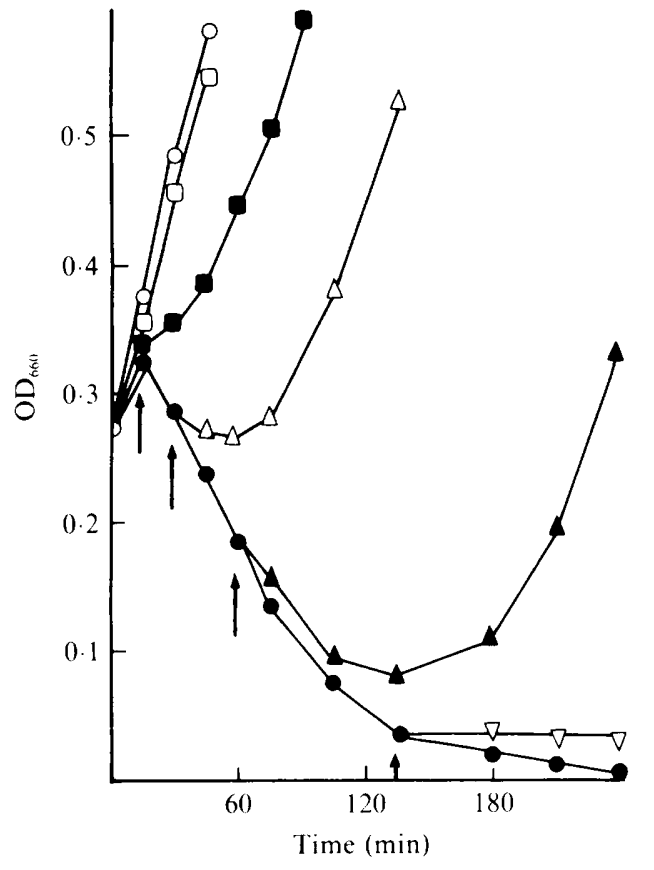

Fig. 5. Reversal by the peptide Ac-L-Lys(Ac)-D-Ala-D-Ala of teicoplanin-induced lysis of $B$. pumilus CCM 1697 . To a culture $(10 \mathrm{ml})$ of exponential phase cells growing in MBD LYC medium, teicoplanin $\left(2 \mu \mathrm{g} \mathrm{ml}^{-1}\right)$ was added at $0 \mathrm{~min}$, followed by the addition of a $250 \mathrm{molar}$ excess of the peptide at different time points (arrows): $15 \mathrm{~min} ; \triangle$. $30 \mathrm{~min}$; $\Delta, 60 \mathrm{~min}: \nabla, 120 \mathrm{~min} ; O$, untreated cells; $\boldsymbol{O}$, teicoplanin without peptide: $\square$, teicoplanin and peptide added at $0 \mathrm{~min}$.

Inhibition of teicoplanin-induced lysis by the peptide $A c-L-L y \cdot s(A C)-D-A l a-D-A l a$

Somma et al. (1984) reported that teicoplanin, like vancomycin (Best \& Durham, 1965; Nieto \& Perkins, 1971), binds to cell walls and forms a complex with peptides related to bacterial peptidoglycan, such as Ac-L-Lys(Ac)-D-Ala-D-Ala. This peptide when used at a 250 -fold molar excess with respect to teicoplanin $(2 \mu \mathrm{g}$ $\mathrm{ml}^{-1}$ ) and when added simultaneously with the antibiotic to cultures of B. pumilus CCM 1687 (Fig. 5) not only protected the cells from lysis but allowed bacterial growth indistinguishable from the control. Broadly similar results were obtained with $M$. luteus (data not shown).

The peptides Ac-L-Lys(Ac)-D-Ala-L-Ala or Ac-LLys(Ac)-L-Ala-D-Ala in a 250 -fold molar excess relative antibiotic did not exert any inhibitory influence on teicoplanin-induced lysis of B. pumilus and Strep. faecalis (data not shown). On the other hand the peptides Ac-LLys(Ac)-D-Ala-Gly and Ac-L-Lys(Ac)-D-Ala-D-Leu, tested under the same conditions, protected the cells from lysis but allowed cell growth to reach only $30-40 \%$ of a control culture. 


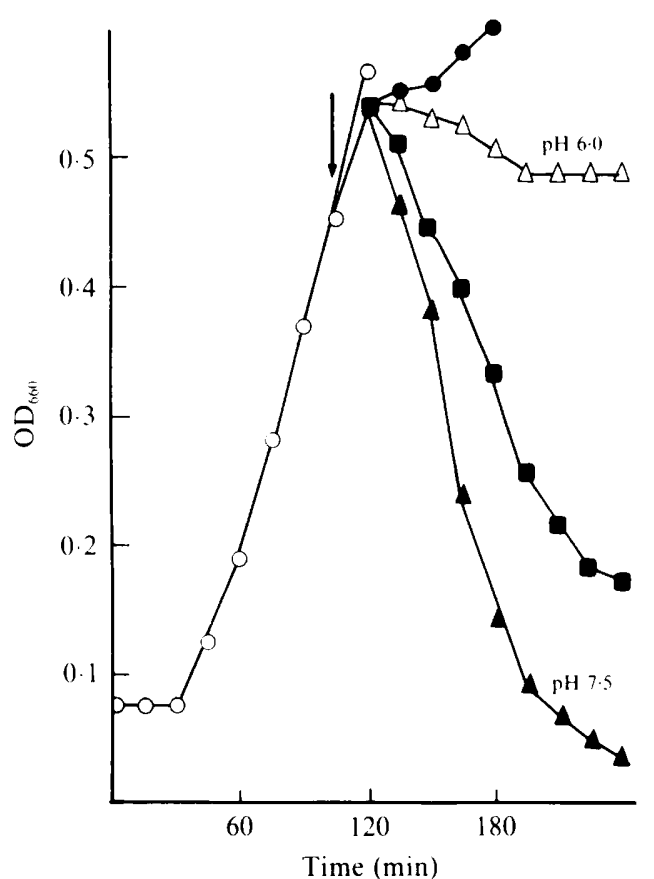

Fig. 6. Effect of a washing step on the lysis of B. pumilus CCM 1697 cells pretreated with teicoplanin. To a culture $(40 \mathrm{ml})$ of exponential phase cells growing in MBD LYC medium, teicoplanin $\left(2 \mu \mathrm{g} \mathrm{ml}^{-1}\right)$ was added at the time indicated by the arrow. After $15 \mathrm{~min}$, the cells were harvested, rapidly washed and resuspended in $10 \mathrm{ml}$ of: $\boldsymbol{\square}$, fresh medium;, fresh medium (pH 7.0) containing Ac-L-Lys(Ac)-D-Ala-DAla in a 250 -fold molar excess; $\triangle, \boldsymbol{\Delta}, 100 \mathrm{~mm}$-Bistris/HCl buffer, adjusted to the indicated $\mathrm{pH}$ values.

Nieto et al. (1972) have similarly observed that the inhibition of growth of B. megaterium KM, Staph. aureus and $M$. lysodeicticus NCTC 2665 by iodovancomycin could be reversed by diacetyl- $\alpha, \gamma$-diaminobutyryl-Dalanyl-D-alanine added in a 38 -fold molar excess relative to the antibiotic.

\section{Effect of teicoplanin pretreatment of bacterial cells on lysis}

A consequence of the binding of teicoplanin to the bacterial cell wall (Somma et al., 1984) is that simple washing of cells pretreated with the antibiotic is not sufficient to prevent lysis. B. pumilus CCM 1697 pretreated with $2 \mu \mathrm{g}$ teicoplanin $\mathrm{ml}^{-1}$ for $15 \mathrm{~min}$, washed and transferred to fresh medium or buffers behaved as if the antibiotic was still present (Fig. 6). Cells suspended in Bistris/ $\mathrm{HCl}$ buffer of $\mathrm{pH} 7.5$ lysed rapidly, but when the buffer was slightly acidic, no extensive lysis was observed. For B. pumilus a $\mathrm{pH}$ value of 6.0 was enough to prevent lysis. On the other hand, cells resuspended in fresh medium at $\mathrm{pH} 7.0$ lysed to the same degree as if the antibiotic was still present. Cells transferred to fresh medium containing Ac-L-Lys(Ac)-D-Ala-D-Ala in a 250fold molar excess relative to the antibiotic did not undergo lysis and, moreover, immediately started to grow. Untreated cells of $B$. pumilus, when suspended in buffer at $\mathrm{pH} 7 \cdot 5$, exhibited only slight lysis, not exceeding $15-20 \%$ of the initial optical density. Peptides such as Ac-L-Lys(Ac)-L-Ala-D-Ala and Ac-L-Lys(Ac)-D-Ala-LAla, when added to teicoplanin-pretreated and washed cells, did not protect the cells from lysis (data not shown) indicating that the $\mathrm{D}-\mathrm{D}$-sequence is indispensable for a reversal of teicoplanin-induced lysis.

The reversal of teicoplanin-induced bacteriolysis by Ac-L-Lys(Ac)-D-Ala-D-Ala occurred only with growing cells. The peptide, at a 250 -fold molar excess, did not confer protection from lysis in buffer ( $\mathrm{pH} 7.5$ ) (data not shown).

\section{Specific effects of teicoplanin}

The results of our studies on the response of bacterial cells to the action of teicoplanin largely coincide with the generally known effects of cell-wall-inhibitory antibiotics including phenomena such as the dependence of the lysis rate on the growth rate and lack of lysis of nongrowing cells.

We have made, in addition, the more unusual observation that teicoplanin, unlike vancomycin and methicillin, induces some lysis in hypertonic medium. This suggests that the antibiotic, as well as inhibiting cell wall biosynthesis, also exhibits some membrane-damaging activity. The molecule of the antibiotic contains acyl residues of $\mathrm{C}_{9}-\mathrm{C}_{10}$ fatty acids (Borghi et al., 1984). This structural feature, making teicoplanin more lipophilic than vancomycin, may favour penetration into the bacterial cytoplasm membrane, thus causing membranedamaging effects.

Another interesting phenomenon is the rather high tolerance of Strep. faecalis to teicoplanin in slightly acidic media. A similar effect of tolerance to penicillin in acidic medium was earlier described by Goodell et al. (1976). Correspondent with this phenomenon is the tolerance of autolysis-defective strains to teicoplanin. The tolerance of autolysis-defective bacteria to penicillin has been reported many times (Rogers \& Forsberg, 1971; Rogers et al., 1983). The clinical importance of these aspects of penicillin action has been underlined by a recent report describing the isolation of penicillin-tolerant autolysisdefective pathogenic bacteria from patients with recurring infections (Horne \& Tomasz, 1977). The teicoplanin tolerance of bacteria in a slightly acidic environment may have comparable clinical implications.

The presence of cell-bound teicoplanin is indispensable for its lytic action in growing cells, as shown by the experiments with the specific peptide Ac-L-Lys(Ac)-D- 
Ala-D-Ala. In buffer alone (with permissive $\mathrm{pH}$ ) the peptide did not protect the cells pretreated with teicoplanin from progressive lysis. The elucidation of this phenomenon requires further studies.

The authors acknowledge the financial support of these studies by the Project CPBR-3.13. They are also indebted to Dr R. Andruszkiewicz for the synthesis of peptides used in these studies. The skilled technical assistance of L. Kasprzak is gratefully aknowledged.

\section{References}

Ayusawa, D., Yoneda, Y., Yamane, K. \& Marno, B. (1975). Pleiotropic phenomena in autolytic enzyme(s) content, flagellation, and simultaneous hyperproduction of extracellular $\alpha$-amylase and protease in a Bacillus subtilis mutant. Journal of Bacteriology 124, 459-469.

Bardonne, M. R., Paternoster, M. \& Coronelli, C. (1978). Teichomycins, new antibiotics from Actinoplanes teichomyceticus nov. sp. II. Extraction and chemical characterization. Journal of Antibiotics 31, 170-177.

Barna, J. C. J., Williams, D. H., Stone, D. J. M., Leung, T. W. C. \& DoDRELl, D. M. (1984). Structure elucidation of the teicoplanin antibiotics. Journal of the American Chemical Society 106, 4895-4902.

BEST, G. K. \& DURHAM, N. N. (1964). Effect of vancomycin on Bacillus subtilis. Archives of Biochemistry and Biophysics 105, 120-125.

BEST, G. K. \& DurhaM, N. N. (1965). Vancomycin adsorption to Bacillus subtilis cell walls. Archives of Biochemistry and Biophysics 111 , 685-692.

Best, G. K., Best, N. H. \& Koval, A. V. (1974). Evidence for participation of autolysis in bactericidal action of oxacillin on Staphylococcus aureus. Antimicrobial Agents and Chemotherapy 6, $825-830$.

Boman, H. G. \& ERIKson, K. E. (1963). Penicillin induced lysis in Escherichia coli. Journal of General Microbiology 31. 339-352.

Borghi, A., Coronelli, C., Faniuolo, L., Allievi, G., Pallanza, R. \& Gallo, G. G. (1984). Teichomycins, new antibiotics from Actinoplanes teichomyceticus nov. sp. IV. Separation and characterization of the components of teichomycin (teicoplanin). Journal of Antibiotics 37, 615-620.

ChMARA, H. \& BorowSKI, E. (1986). Bacteriolytic effect of cessation of glucosamine supply, induced by specific inhibition of glucosamine-6phosphate synthetase. Acta Microbiologica Polonica 35, 15-27.

FEIN, J. E. \& RoGERS, H. I. (1976). Autolytic-enzyme deficient mutants of Bacillus subtilis 168. Journal of Bacteriology 127, 1427-1442.

Fietta, A., Bersani, C., Mangiarotti, P. \& Gialdroni-Grassi, G. (1983). In vitro activity of teichomycin against isolated Grampositive bacteria. Chemotherapy 29, 275-282.

GoODELl, E. W., Lopez, R. \& Tomasz, A. (1976). Suppression of lytic effect of beta-lactams on Escherichia coli and other bacteria. Proceedings of the National Academy of Sciences of the United States of America 73, 3293-3297.

GreEnwood, D., BidGoOd, K.\& Turner, M. (1987). A comparison of the responses of staphylococci and streptococci to teicoplanin and vancomycin. Journal of Antimicrobial Chemotherapy 20, 155-164.

van Heijenoort, Y., Leduc, M., Singer, H. \& van Heijenoort, J (1987). Effects of moenomycin on Escherichia coli. Journal of General Microbiology 133, 667-674
Herbold, D. R. \& Glaser, L. (1975). Bacillus subtilis $N$-acetylomuramic acid L-alanine amidase. Journal of Biological Chemistry 250 , 1676-1682.

HORnE, P. \& Tomasz, A. (1977). Tolerant response of Streptococcus sanguis to beta-lactams and other cell-wall inhibitors. Antimicrobial Agents and Chemotherapy 6, 825-830.

Kitano, K. \& Tomasz, A. (1979). Triggering of autolytic cell-wall degradation in Escherichia coli by beta-lactam antibiotics. Antimicrobial Agents and Chemotherapy 16, 838-848.

Lopez, R., Ronda-Lein, C., TAPIA, A., Waks, S. B. \& Tomasz, A (1976). Suppression of the lytic and bactericidal effects of cell-wall inhibitory antibiotics. Antimicrobial Agents and Chemotherapy 10, $697-706$.

Neu, H. \& Labthavikul, P. (1983). In vitro activity of teichomycin compared with those of other antibiotics. Antimicrobial Agents and Chemotherapy 24, 425-428.

Nieto, M. \& Perkins, H. R. (1971). Physicochemical properties of vancomycin and iodovancomycin and their complexes with diacetylL-lysyl-D-alanyl-D-alanine. Biochemical Journal 123, 773-787.

Nieto, M., Perkins, H. R. \& ReYnolds, P. E. (1972). Reversal by a specific peptide (diacetyl- $\alpha, \gamma$-L-diaminobutyric-D-alanyl-D-alanine) of vancomycin inhibition in intact bacteria and cell-free preparations. Biochemical Journal 126, 139-149.

Pallanza, R., Berti, M., Goldstein, B. P., Mapelli, E., Randisi, E., SCOTTI, R. \& ARIOLI, V. (1983). Teichomycin in vitro and in vivo evaluation in comparison with other antibiotics. Journal of Antimicrobial Chemotherapy 11, 419-425.

Parenti, F., Beretta, G., Berti, M. \& Arioli, V. (1978). Teichomycins, new antibiotics from Actinoplanes teichomyceticus nov. sp. I. Description of the producer strain, fermentation studies and biological properties. Journal of Antibiotics 31, 276-281.

ReYNolds, P. E. (1971). Peptidoglycan synthesis in bacilli II Characteristic of protoplast membrane preparations. Biochimica et Biophysica Acta 237, 255-272.

Rogers, H. J. \& ForsBerG, C. W. (1971). Role of autolysins in killing of bacteria by some bactericidal antibiotics. Journal of Bacteriology 108, 1235-1243.

Rogers, H. J., Thurman, P. F. \& Burdett, I. D. J. (1983). The bactericidal action of $\beta$-lactam antibiotics on an autolysin-deficient strain of Bacillus subtilis. Journal of General Microbiology 129, 465478

Rosenthal, R. S., Jungkind, D., Daneo-Moore, L. \& Shockman, G. D. (1975). Evidence for the synthesis of soluble peptidoglycan fragments by protoplasts of Streptococcus faecalis. Journal of Bacteriology 124, 398-409.

Somma, S., Gastaldo, L. \& Corti, A. (1984). Teicoplanin, a new antibiotic from Actinoplanes teichomyceticus nov. sp. Antimicrobial Agents and Chemotherapy 26, 917-923.

TOMASZ, A. \& HüLTJE, J.-V. (1977). Murein hydrolases in the lytic and killing action of penicillin. In Microbiology 1977, pp. 209-215. Edited by D. Schlessinger. Washington, DC: American Society for Microbiology.

Tomasz, A. \& WaKs, S. (1975). Enzyme replacement in a bacterium, phenotypic correction by the experimental introduction of the wild type enzyme into a live enzyme defective mutant Pneumococcus. Biochemical and Biophysical Research Communications 65, 1311-1319.

Tuomanen, E., Cozens, R., Tosch, W., ZaK, A. \& Tomasz, A. (1986). The rate of killing of Escherichia coli by $\beta$-lactam antibiotics is strictly proportional to the rate of bacterial growth. Journal of General Microbiology 132, 1297-1304. 